\author{
Mednikova M.B. ${ }^{1)}$, Kazansky P.R. ${ }^{2)}$ \\ 1) Institute of Archaeology of the Russian Academy of Sciences, \\ Dm. Ulyanova str., 19, Moscow, 117036, Russia; \\ 2) Systems for Microscopy and Analysis $L L C$, \\ 45 Skolkovskoe sh., 121353 Moscow, Russia
}

\title{
NON-DESTRUCTIVE 3D MICROSCOPY IN THE STUDY OF PATTERNS OF BIOLOGICAL ADAPTATION AMONG FOSSIL AND RECENT HOMO
}

Introduction. Metabolic rate and heat exchange parameters play a major role in human biological adaptation in different climes. Microscopic examination and volumetric characterization of bone tissue will help us to understand how common adaptive patterns of human constitution may define variations in metabolic rate on microstructural level.

The aim of the study was to test microstructural diversity of bone tissue of fossil Asian and European Pleistocene hominids of differing origin, establishing distinctive features in forms adapted for cold and warm climes.

Materials and methods. We apply non-destructive volumetric technique for evaluation of vascular net density in compact bone. Segmentation of Haversian canals and accurate estimation of their relative volume fraction gives the opportunity to estimate the density and capacity of the vascular system of the bone tissue in a proxy way. Radiological images of dorsal compact of medial and distal phalanges were studied (Neanderthals from Altai and Europe; CroMagnons; recent humans of Arctic and African origin).

Results. High vascularization of compact clearly demonstrates that European Neanderthals and the majority of AMH were adapted to the Glacial Age. But Kostenki 14 (Eastern Europe) and Strashnaya 4 (Altai) have features in common with humans of recent tropic origin.

Specimens of Neanderthals which lived in Altai region where glaciers never occurred are more diverse. Hypothetically the milder climate favored the existence of a wider adaptive norm reflecting patterns of former environments. Somewhat ambiguous morphological patterns of Denisova 9 and Okladnikov 2, 5 may reflect various episodes of Neanderthal migration to Siberia and their hybridization with people of tropical ancestry, most probably the early AMH. Chagyrskaya Neanderthal demonstrates a hyper-cold adaptation.

Conclusion. Diversity in microstructural patterns of the Pleistocene people's skeletal system gives evidence that both Neanderthals and CroMagnons were polymorphic in their adaptive reactions and presumably included both warm and cold adapted forms.

Keywords: Neanderthals; CroMagnons; heat exchange; vascularization of compact of tubular bones 


\section{Introduction}

Thermoregulation is a key factor of human biological adaptation. Distinct morphological and physiological differences are shown to exist between native inhabitants of Arctic and tropical regions, largely determining their metabolic and heat exchange rates.

Morphological adaptation expresses itself in a strong relation between body size/form and ambient temperature, e.g. as in well-known zoological Bergmann and Allen rules. Among physiological and biochemical adaptations reducing or increasing the temperature gradient between the body and the environment, blood circulation and redistribution effectively regulate heat exchange [So, 1980].

Based on numerous studies of native populations T.I. Alexeeva [1977] proposed the term "adaptive types" of biological reaction to environmental conditions. The basic assumption was that natives of North had a higher metabolic rate. The representatives of the Arctic adaptive type (inhabitants of the Northern (high) altitudes (higher than $66^{\circ} 33^{\prime}$ ), who live in conditions of severe climate with low temperatures, strong wind, humidity, high solar radiation and hypoxia, in general show such biological patterns as heavily-built, large cylindrical chest, athletic built, especially in the upper part of body, robust skeleton, and high volume of medullary space within tubular bones. Adaptive reactions of highlanders are similar. They live in conditions of low atmospheric pressure and low atmospheric oxygen content, low temperatures, zonality, and demonstrate high volume of medullary space of tubular bones, intensive blood formation (hematopoiesis) and round chest. The most distant and the most ancient is the tropical adaptive type. It combines features such as low density of body built, flattened chest; "narrow" build and low metabolic rate.

The particular observations show that extremities were more susceptible to cold in those populations. While the body of Arctic or highland inhabitant is well protected, the hands, are subject to cold since the mittens must be taken off during certain activities. It was shown that non-coldexposed Coastal Peruvian Quechua Indians had responses similar to those of cold-exposed highland natives [Little et al., 1971]. Eskimo representatives, out of the Arctic for a period of 9 months, eating a
Western diet and living a Western lifestyle, continued to respond well in cold [Eagan, 1963].

Traditionally microscopic examination of human bone tissue was associated with destructive techniques of sample preparation, complicated pretreatment and subsequent study by light or polarized light microscopy.

Macerated (dry) bones from archaeological excavations have been studied with the goal to determine developmental age as well as to diagnose palaeopathological features [Kerley, 1965; Frost, 1987; Stout, Teitelbaum, 1976; Stout, Stanley, 1991; Stout, Paine, 1992; Iwaniec et al., 1998; Schultz, 2001 etc.].

The compact of human tubular bone has a complex hierarchical microstructure that can be analyzed for different morphometric parameters, e.g. the relative inner robusticity of walls or histomorphometric features [Buckwalter et al., 1995].

The appearance of smaller osteons in cortical bones of Late Pleistocene human populations was noted [Abbott et al., 1996; Pfeiffer, Zehr, 1996]. Further examination of archaeological samples increased our knowledge of microstructural variability within human skeletons and between modern human populations [Pfeifer, 1998]. S. Pfeifer compared three samples of historically known individuals: ribs and femora from 18th century Huguenots in England, ribs and femora from 19th century British settlers in Canada, and ribs from 20th century South Africans of different origin. Analyzing values of total osteon cross-section area and Haversian canal cross-section area Pfeifer found no significant variations for either values between sexes and between samples, and no influence of biological age in most instances. But the size of osteons was different in different bones (for femora they were larger than for ribs). And Haversian canal area was discovered to be more variable than osteon area, especially in the latest sample combining people of various origins.

Moreover, other studies revealed variations in histomorphology and histomorphometry within and between human bones [Robling, Stout, 1999; Mulhern, 2000; Qui et al., 2003; Pirock et al., 2006 etc]. This is the reason we present the data of microscopic examination of manual phalanges only in this particular study. 
Originally we took interest in non-destructive microscopic examination of fossil phalanges in 2013 when we had the unique opportunity to study a structure of distal phalanx of the "Denisova girl" [Mednikova et al., 2013]. Shortly before that, based on mtDNA analysis, this fossil was attributed to a new species (Denisovans) that diverged from the common ancestor of modern humans and Neanderthals about 1 million years ago (confidence limits, 1,313,500-779,300 BP) [Krause et al., 2007]. Two fragments remaining after ancient mtDNA sampling were subjected to micro CT examination, and their 3D images and virtual slices were generated using tomography software. The tomograms were reconstructed from 4321 equidistant angular projections in the $0-360^{\circ}$ range. 3D image analysis yielded volumetric parameters of relevant histological features, e.g. osteon sizes measured on virtual crosssections of the metaphyseal part, ranging from relatively small (approximately $210 \mu \mathrm{m}$ ) to large (above $514 \mu \mathrm{m}$ ). Large primary osteons with wide Haversian canals and numerous Volkmann's canals observed were typical for immature cortical bone. Another osteon structure was observed on virtual cross-sections of the diaphysis. Large parts of the cortical bone were filled with lamellar tissue and rare osteons with diameters below $210 \mu \mathrm{m}$. Osteon size was less variable here, mostly ranging between 125-202 $\mu \mathrm{m}$.

In our study of manual phalanges of adult fossil humans, we focused on the variability of compact bone vascular system development among Neanderthals and Upper Palaeolithic H. sapiens [Mednikova, Dobrovolskaya, 2014]. We first applied this method of radiological examination to the scanning of two Neanderthal specimens from excavations of Altai Caves (Okladnikov 2, Chagyrskaya $56 \mathrm{~b})$, two middle phalanges of East-European CroMagnons (Kostenki 14, Sunghir 1) and two control archaeological samples of recent humans of tropical and Arctic origin. The high variability discovered there could be interpreted in different ways, including occupational or genetic differences.

The vascular system of human compact bone tissue [Jaffe, 1929] may be considered as a feature and measure of biological adaptation taking place in the glaciation and warming periods occurring in Eurasia during Quaternary period [Dobrovolskaya, Mednikova, 2016; Mednikova, 2018, 2020a]. Radi- ating populations of the genus Homo (e.g. the late Homo erectus, Neanderthals, Denisovans, early anatomically modern humans) have developed in the "out-of-tropical" climatic environment. In a new environment populations should acquire new adaptive biological features. Adaptation to cold stress was associated with increase in heat exchange, the need for more intensive oxidation resulting in a more developed vascular system able to supply more oxygen to tissues. Blood vessels of the bone tissue are the part of a common cardiovascular net and reflect its condition [Asghar, Kumar, Narayan, 2020]. Moreover, that makes it possible for evolutionary anthropologists to infer metabolic characteristics from microstructure of bone material.

A growing number of samples, together with new chronology and origin genetics data of the late Pleistocene humans, provide means to study microstructural patterns of fossil tubular bones (especially vascular canals) relative to biological adaptation.

\section{Materials and Methods}

The European Neanderthals are represented by the samples from the Musée de l'Homme in Paris (La Ferrassie 1, Dordogne) and the Museum of Anthropology and Ethnography (Kunstkamera) RAS in St. Petersburg (Kiik-Koba 1, Crimea).

The Neanderthals from Asia are represented by small tubular bones from excavations in Okladnikov, Chagyrskaya and Denisova caves of Altai middle-highland. After morphological examination [Mednikova, 2011, 2013; Mednikova, Shunkov, Markin, 2017] samples from Chagyrskaya and Denisova were studied by palaeogenetists who supported their Neanderthal attribution [Sawyer, 2016; Mafessoni et al., 2020]. The genetic Neanderthal attribution of remains from Okladnikov Cave was identified earlier [Krause et al., 2007].

Okladnikov 2. A middle phalanx of the 3rd or 4th digit of the left (?) hand was found in the sq. Г-4 of the layer 4 at Okladnikov Cave in 1984. If it is a phalanx of the $4^{\text {th }}$ digit, it is larger than phalanges of Shanidar males.

Okladnikov 5. A medial phalanx was found in layer 3-1.

Chagyrskaya $56 b$ middle phalanx or Chagyrskaya 16-3-12 [Mednikova, Shunkov, Markin, 2017] belonged to the same Neanderthal hand as 


\section{6}

preliminary described distal phalanx Chagyrskaya 56c [Viola, Mednikova, Buzhilova, 2018; Mednikova, 2020b].

A manual distal phalanx Denisova 9 or, after genetic study, Altai 2 from an adult Neanderthal individual has been found in stratum 12 of the Denisova Cave [Mednikova, 2013; Sawyer, 2016].

The Upper Palaeolithic humans are represented in our study by variety of European and Siberian forms. The earliest one of anatomically modern individuals in Europe is the young male from the site of Kostenki 14 (Markina Gora) [Marom et al., 2012; Nalawade-Chavan, McCullagh, Hedges, 2014].

Other samples originated from excavations of the nearby site of Kostenki 8 (Telmanovskaya site) and were found by an expedition of the Leningrad branch of the Institute of Archaeology of the Academy of Science of the USSR (supervised by A.K. Rogachev), presumably in 1959. The morphological examination of specimens TIl 175 and TIl 173 showed them to be the middle manual phalanges of different individuals [Медникова, Моисеев, Хартанович, 2016].

The hand remains of Sunghir 1 male were a part of special attention of morphologists, and the latest publication considered data of microCT scanning [Хрисанфова, 1984; Медникова, 2012; Trinkaus et al., 2014; Mednikova, Shunkov, Markin, 2017].

The middle phalanx of female from Abri Pataud (Musée de l'Homme, No. 26227) represents a morphology typical of later Western-European $H$. sapiens of the Proto-Magdalenian time.

A distal manual phalanx Strashnaya 4 of the Upper Palaeolithic Homo sapiens was found in 2015 in Pleistocene stratum 31, horizon 2 of the Strashnaya cave $120 \mathrm{~km}$ to the south-west of the Denisova Cave. It was identified as anatomically modern [Mednikova, 2020b].

All middle phalanges listed above were subjected to microtomography in order to nondestructively study the inner structure of the samples and their robusticity. Samples from the Musée de l'Homme were studied using local equipment. The resolution of the ordinary microCT appeared to be not enough to measure diameters of all osteons at the virtual cross-section of midshaft dorsal com- pact, but it became possible to estimate $3 \mathrm{D}$ parameters of Haversian canals.

All other samples were scanned using the Xradia Versa XRM-500 X-ray 3D microscope combining traditional MicroCT with an additional in-built optical magnification system. The same equipment was previously used for studying the phalanx of the girl from Denisova Cave [Mednikova et al., 2013].

For example, for sample 6 (Kostenki 14) the point X-ray source was $<2 \mu \mathrm{m}$, (full-spectrum $\mathrm{W}$ without filters, $40 \mathrm{kV} / 75 \mu \mathrm{A}$ ). Source to sample distance was $10 \mathrm{~mm}$; source to detector distance was $9 \mathrm{~mm}$; optical magnification after scintillator was $4 \times$. The tomogram was reconstructed from 2000 equidistant angular projections in the $0-360^{\circ}$ range with $4 \mathrm{~s}$ exposition. Projection images were obtained with $4 \mathrm{Mp}$ camera at $2 \times$ binning. Reconstructed voxel size $3.58 \mu \mathrm{m}$.

Radiological 3D images of dorsal compact at midshaft level of manual phalanges of the 5 th -2 nd ray of various fossil forms were taken (Table 1 , Fig. 1). Xradia proprietary acquisition and tomography software was used to create 3D models and virtual cross-sections, and also to measure osteons and Haversian canals diameters. The central portion of the dorsal wall was selected for segmentation of vascular canal system (Fig. 2). Then with help of the Avizo software vascular volumes were calculated (Fig. 3). The relative development of vascular system was estimated as an index value which is the ratio of vascular volume and the common volume of selected area at the central third of the dorsal compact.

\section{Results}

The index representing the relative development of vascular volume at the central part of dorsal compact was low in young adult Egyptian (1.5) and relatively high in young adult Eskimo male (4) (Table 2).

This ratio shows a notably wide range of inter-individual variation, which is typical of fossil specimens of both Neanderthals and the Upper Palaeolithic anatomically modern humans. The highest development of vascular system was noted in Neanderthal from Chagyrskaya (index value: 9), in the "classic" European Neanderthals La Ferrassie 1 (7.4) and Kiik-Koba 1(5), in Altai Neanderthal
•• Вестник Московского университета. Серия ХХIII. • Антропология • № 1/2021: 93-108 •
- Moscow University Anthropology • Bulletin • 2021, no. 1, pp. 93-108• 
Table 1. List of samples

Таблица 1. Список образцов

\begin{tabular}{|c|l|l|c|c|c|}
\hline $\begin{array}{c}\text { No. of } \\
\text { specimen }\end{array}$ & \multicolumn{1}{|c|}{ Specimen } & \multicolumn{1}{|c|}{ Taxon } & Hand medial phalanx & Sex & $\begin{array}{c}\text { Age, } \\
\text { years }\end{array}$ \\
\hline 1 & La Ferrassie 1 & European Neanderthal & 4th digit, right & Male & $40-55$ \\
\hline 2 & Kiik-Koba 1 & European Neanderthal & 2nd digit, right & Male & $40-49$ \\
\hline 3 & Okladnikov 2 & Neanderthal in Altai & 4th digit, left & Male & $30-39$ \\
\hline 4 & Okladnikov 5 & Neanderthal in Altai & 2nd digit, right & Female & $25-39$ \\
\hline 5 & $\begin{array}{l}\text { Chagyrskaya 16-3- } \\
\text { 12 or Chagyrskaya }\end{array}$ & Neanderthal in Altai & 2nd digit, right & Female & $25-39$ \\
\hline 6 & Koc. & Upper Paleolithic H. sapiens & 4th digit, right & Male & $25-29$ \\
\hline 7 & Kostenki 8 TII 175 & Upper Paleolithic H. sapiens & 3rd digit (?) & Male & $25-39$ \\
\hline 8 & Kostenki 8 TII 173 & Upper Paleolithic H. sapiens & 4th digit, right & Male & $25-39$ \\
\hline 9 & Sunghir 1 & Upper Paleolithic H. sapiens & 2nd digit, right & Male & $35-45$ \\
\hline 10 & Abri Pataud 26227 & Upper Paleolithic H. sapiens & 2nd digit, right & Female & $20-29$ \\
\hline 11 & Ancient Eskimo & Recent H. sapiens & 2nd digit & Male & $20-29$ \\
\hline 12 & Ancient Egyptian & Recent H. sapiens & 2nd digit & Male & $20-29$ \\
\hline & & & Distal manual & & \\
\hline 13 & $\begin{array}{l}\text { Dhalanx } \\
\text { 2) SP2990 }\end{array}$ & Altai Neanderthal & $3^{\text {rd }}$ or 4 th digit & Male & Adult \\
\hline 14 & Strashnaya 4 & Upper Paleolithic H. sapiens & $5^{\text {th } \text { digit (?) }}$ & Female & $\begin{array}{c}\text { Adult or } \\
\text { young adult }\end{array}$ \\
\hline & & & & \\
\hline
\end{tabular}

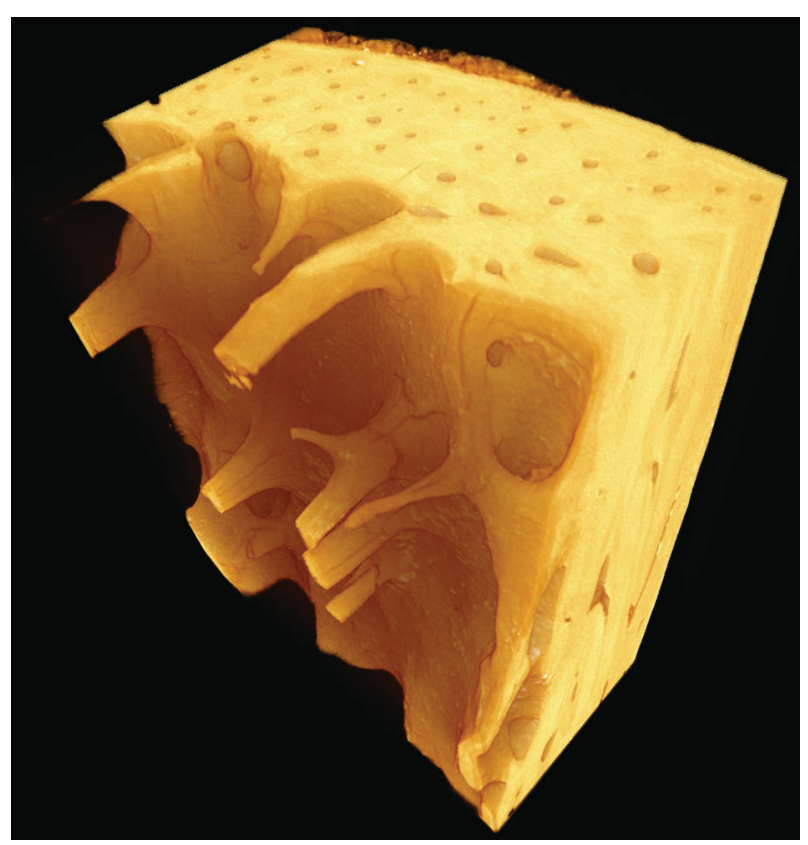

Figure 1. $3 D$ virtual image of dorsal wall of the middle manual phalanx at the midshaft. Sample of bone tissue of the Upper Palaeolithic human Sunghir 1

Рисунок 1. Трехмерное виртуальное изображение дорзальной стенки медиальной фраланги кисти на уровне середины диафиза. Образец костной ткани верхнепалеолитического человека Сунаирь 1 


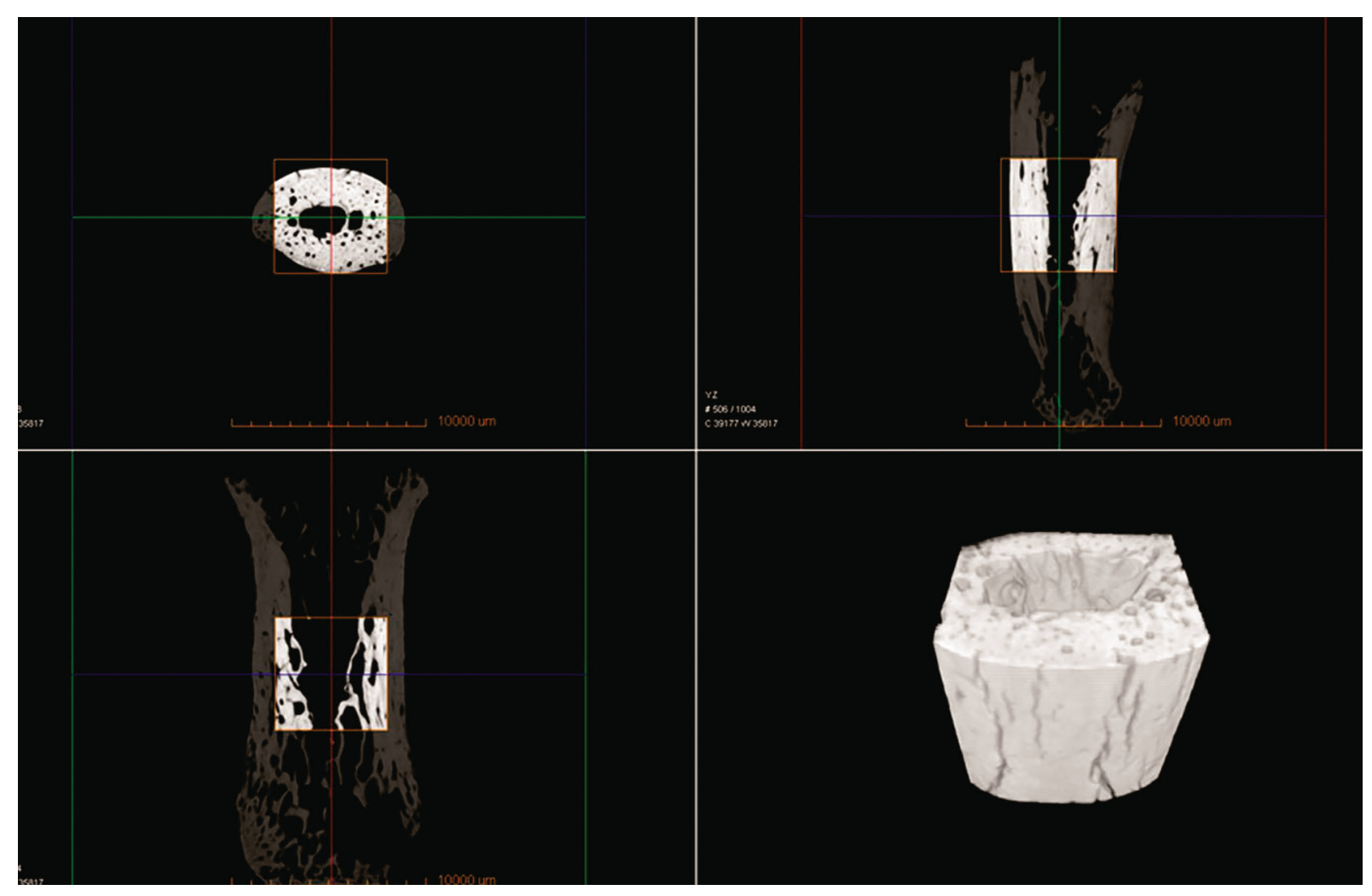

Figure 2. Choice of area of the study

Рисунок 2. Выбор места исследования

Denisova 9 (6.3) and also in many CroMagnons Abri Pataud 26227 (5), individual TII 173 from site Kostenki 8 (4.18), Sunghir 1 (4). The compact bone of this group of fossil humans may be described as well-nourished by microscopic blood vessels during lifetime. The general metabolic rate reflecting oxygenation of bone tissue for these people is comparable with "arctic" or even "hyper-arctic" values.

The other distinctive sample of the late Pleistocene humans demonstrates relatively low development of vascular system of the bone. Among them there are both the Upper Palaeolithic $\mathrm{H}$. sapiens Kostenki 14 (2) and Strashnaya 4 (2.16), as well as both Neanderthals from Okladnikov cave (2 and 1.49). The male TII 175 from Kostenki 8 site seems to adjoin this group with "intermediate" value of relative vascular volume (3.2). That presumably means the low metabolic level of these individuals maybe close to the "tropic" values or be moderate in case of Kostenki 8.

Other point that should be considered is the prominence of cortical thickness in tubular bones, while hypothetically the inner robusticity of tubular bones may influence the common volume of Haversian canals and blood vessels of the compact bone.

Previous study of inner robusticity of the middle and distal phalanges of these specimens revealed that fossil humans vary greatly on this characteristic feature [Mednikova, Shunkov, Markin, 2017; Mednikova, 2020b]. The index of corticalization (\% CA) describing the inner robusticity of the diaphysis, i.e. relative thickness of the cortical layer, varied for the Upper Palaeolithic humans between the most thick-walled middle phalanx of Kostenki 14 and the most thin-walled phalanx of Sunghir 1. The highest difference of inner robusticity of middle phalanges among Neanderthals was detected in the Altai region (Okladnikov 5 and Chagyrskaya 56c).

Study of distal phalanges from Altai caves confirmed the inner gracility of tubular bones for different individuals from Chagyrskaya. It must be also noted that high corticalization at the midshaft is a common feature in Denisova 9 and the modern human Strashnaya 4 [Mednikova, 2020b]. 


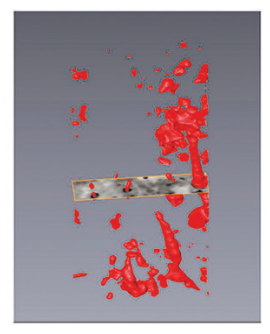

1

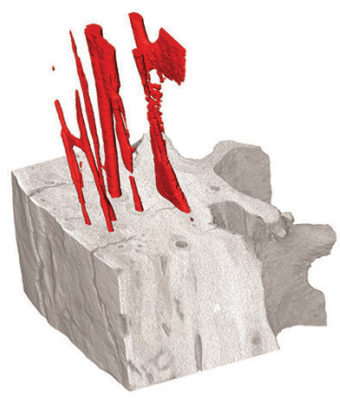

2

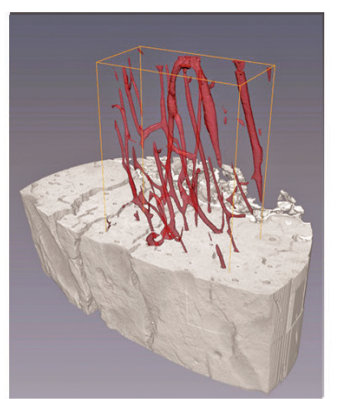

3

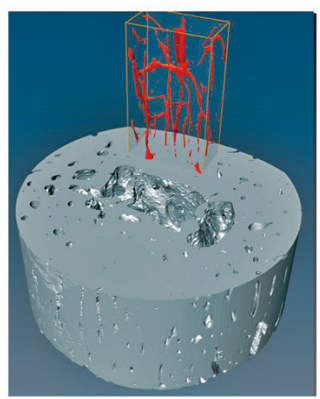

4

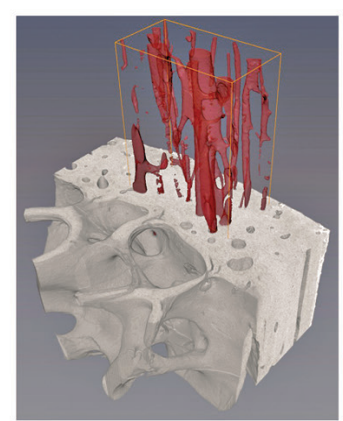

5

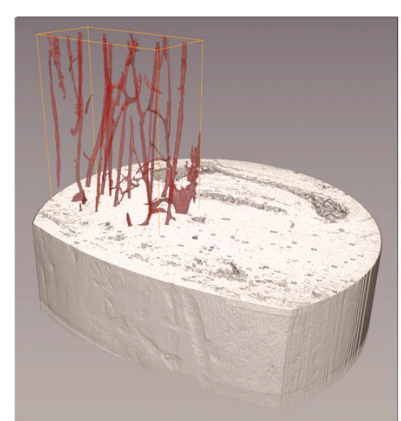

6

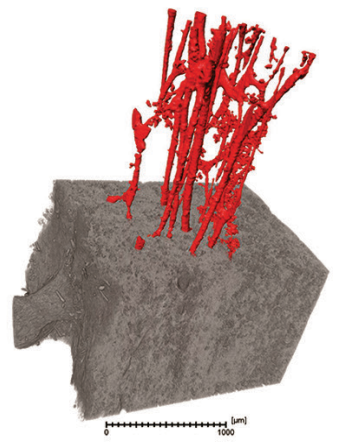

7

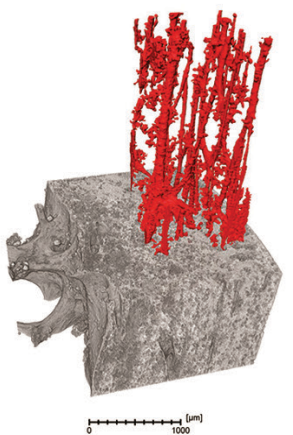

8

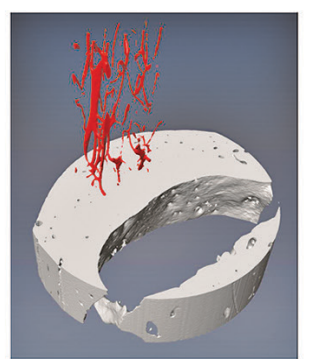

12

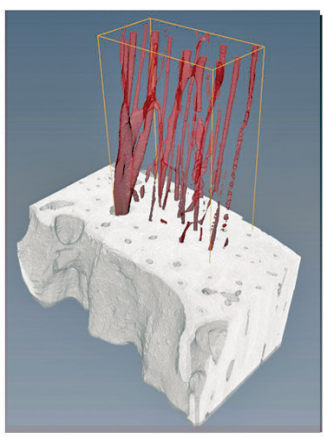

9

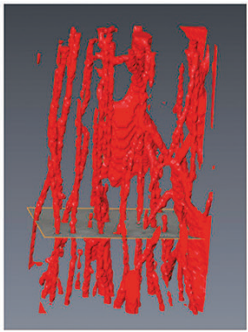

10

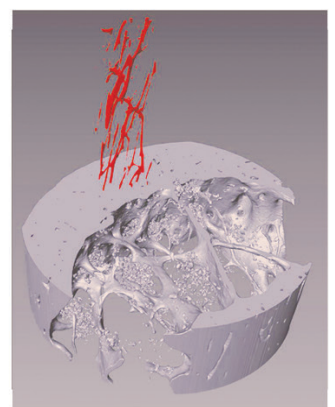

11

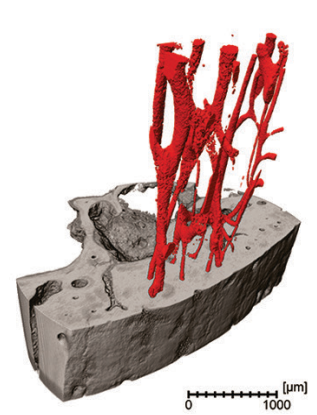

13

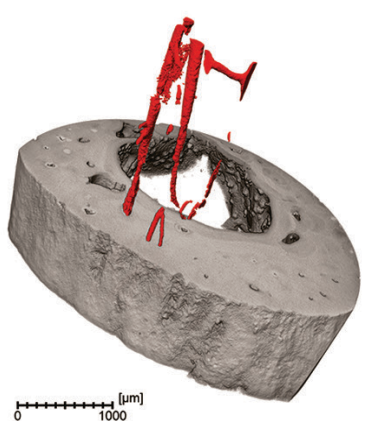

14

Figure 3. Segmentation of samples of fossil and recent humans. List of samples as in table 1 Рисунок 3. Сегментация образцов костной ткани ископаемых и современных людей. Перечень образцов как в таблице 1

• Вестник Московского университета. Серия ХХIII. • Антропология • № 1/2021: 93-108 • $\bullet$ Moscow University Anthropology • Bulletin • 2021, no. 1, pp. 93-108 • 
Table 2. Microstructural patterns of fossil and recent samples

Таблица 2. Микроструктурные особенности ископаемых и современных образцов

\begin{tabular}{|c|c|c|c|c|c|c|}
\hline 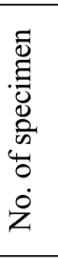 & Specimen & $\begin{array}{l}\text { Min - Max } \\
\text { diameters of } \\
\text { osteons, central } \\
\text { third of dorsal } \\
\text { compact at the } \\
\text { midshaft, } \mu \mathrm{m}\end{array}$ & $\begin{array}{l}\text { Min - Max } \\
\text { diameters of } \\
\text { Haversian } \\
\text { canals, } \mu \mathrm{m}\end{array}$ & $\begin{array}{c}\text { Vascular } \\
\text { volume at the } \\
\text { central part of } \\
\text { dorsal } \\
\text { compact, \% }\end{array}$ & $\begin{array}{c}\% \mathrm{CA} \\
\text { at midshaft }\end{array}$ & $\begin{array}{l}\text { Adaptation to } \\
\text { cold or hot } \\
\text { environment } \\
\text { based on } \\
\text { development of } \\
\text { vascular system } \\
\text { of the compact }\end{array}$ \\
\hline 1 & La Ferrassie 1 & $190-540$ & $56-77$ & 7,4 & 76,57 & Cold-adapted \\
\hline 2 & Kiik-Koba 1 & $258-353$ & $49-166$ & 5 & 74,39 & Cold-adapted \\
\hline 3 & Okladnikov 2 & $212-413$ & $35-65$ & 2 & 77,88 & Warm-adapted \\
\hline 4 & Okladnikov 5 & $114-468$ & $55-100$ & 1,49 & 89,87 & Warm-adapted \\
\hline 5 & $\begin{array}{l}\text { Chagyrskaya 16-3- } \\
12 \text { or Chagyrskaya } \\
56 \mathrm{c} \text {. }\end{array}$ & $122-322$ & $35-180$ & 9 & 56,32 & Cold-adapted \\
\hline 6 & Kostenki 14 & $180-255$ & $25-45$ & 2 & 95,6 & Warm-adapted \\
\hline 7 & $\begin{array}{l}\text { Kostenki } 8 \mathrm{~A} \text { or TII } \\
175\end{array}$ & $99-227$ & $28-61$ & 3,2 & 80,15 & Intermediate \\
\hline 8 & $\begin{array}{l}\text { Kostenki 8B or TII } \\
173\end{array}$ & $94-320$ & $33-116$ & 4,18 & 75,97 & Cold-adapted \\
\hline 9 & Sunghir 1 & $95-285$ & $30-180$ & 4 & 69,61 & Cold-adapted \\
\hline 10 & Abri Pataud 26227 & $94-320$ & $33-116$ & 5 & 80,17 & Cold-adapted \\
\hline 11 & Ancient Eskimo & $150-290$ & $43-107$ & 4 & 63,18 & Cold-adapted \\
\hline 12 & Ancient Egyptian & $100-320$ & $23-115$ & 1,5 & 77,31 & Warm-adapted \\
\hline 13 & $\begin{array}{l}\text { Denisova } 9 \text { (Altai } \\
\text { 2) SP2990 }\end{array}$ & $160,7-392,7$ & 3 & 6,3 & 5 & bted \\
\hline 14 & Strashnaya 4 & $145-321,5$ & $32-149$ & 2,16 & 82,61 & Warm-adapted \\
\hline
\end{tabular}

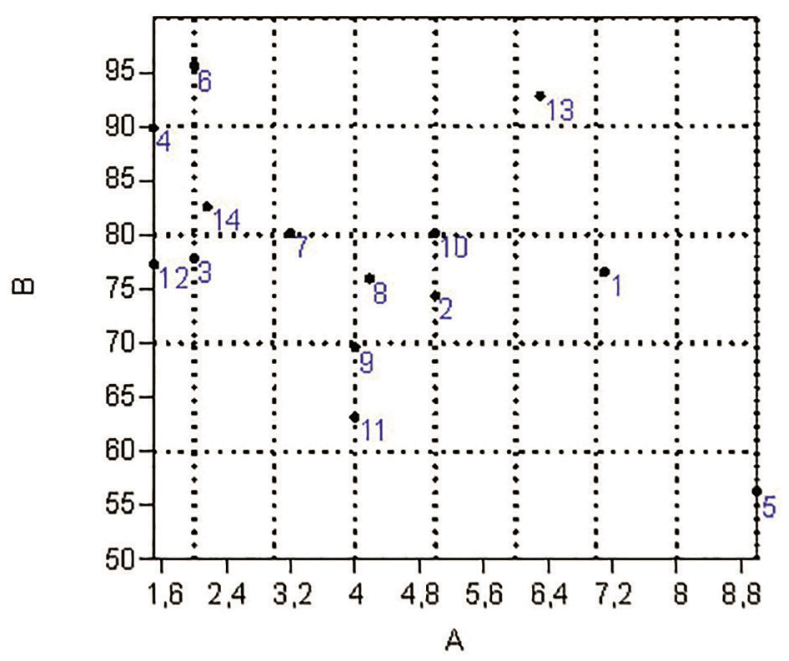

Figure 4. Ratio of the relative vascularization of dorsal compact of middle manual phalanges $(B)$ and the index of corticalization, \% CA (A). List of samples as in table 1

Рисунок 4. Соотношение показателя васкуляризации дорзальной компакты фралана кисти (B) и индекса кортикализации, \% СА (A). Перечень образцов как в таблище 1 
When we compare the relative vascularization of dorsal compact with \% CA values, we find that fossil samples $3,14,4,6$, lesser - number 7 , come near the recent sample of an individual of African ancestry (Fig. 4). Phalanges 9, 8, 2, 10 are closer to young adult Eskimo male, having higher inner robusticity than this recent sample. Specimen 1 shows higher vascularization in comparison with listed fossil samples. Individual number 5 was particular because of phalangeal walls extraordinary gracility (lower than for recent Arctic inhabitant) and hyper-vascularity of compact. Another separated phalanx number 13 combines very high corticalization with great impact of vascular system of the compact bone.

\section{Discussion}

Microscopic examination and 3D volumetric microstructure analysis of fossil and recent samples reveals high variety, possible reflecting different degrees of biological adaptation to current or historic environmental conditions. These peculiarities need to be reviewed in relation to origins of the late Pleistocene humanities, as well as to general factors determining tubular bone structure variability.

The diaphyseal structure of tubular bones of ancient and modern humans was most often considered in terms of their occupational stress. The results of the research on the long-term dynamics of the inner robusticity of the greater tubular bones appeared to be the basis for the conception of the leading role of biomechanical properties of bone and their influences during bone morphogenesis [Ruff, 2000]. It was supposed, that the inner robusticity of the humerus and femur has been steadily decreasing from the Early Pleistocene to modern times.

It was noted that the early anatomically modern humans are closer by the inner robusticity to archaic humans than to modern populations. In addition, $H$. erectus display the most distinctive pattern: their diaphyseal robusticity was a result of both narrowing of the medullary cavity and an extension of the periosteal layer.

Previous comparative study of the middle manual phalanges of the Pleistocene humans by microCT was devoted to confirmation for the hypothesis of the increased inner robusticity of tubular hand bones in Neanderthals as compared to the
Upper Paleolithic European H. sapiens [Mednikova, Shunkov, Markin, 2017]. But the results demonstrate that the phalanges of the European $\mathrm{AMH}$ were usually more thick-walled. Contrary to expectations, relatively thickness of walls does not depend on either the sex or the age of an individual. Even the oldest among the fossils studied La Ferrassie 1 Neanderthal has not shown the bone resorption typically associated with osteoporosisneither in dorsal, nor in ventral walls of diaphysis, although he exhibits numerous degenerative changes in various parts of the skeleton, and obliteration of cranial sutures.

It may be assumed that patterns of adult tubular bones of recent people of Arctic origin combine relatively thin walls with their high vascularization, and that people of tropical ancestry may have relatively thick compact with low development of blood vessels inside Haversian canals. It was discovered that people of African ancestry have generally denser bone mass than Europeans. Europeans demonstrate greater cortical porosity and larger osteon size than Africans. The young African Americans have larger cortical area, lower urinary calcium levels, lower bone resorption, slower bone turnover rate, greater rate of subperiosteal opposition [Cho et al., 2002, 2006].

It was reported that fragility fracture rates in South Africa are lower in black adults and children than in whites. In adults of this study cortical bone of blacks is thicker, less porous, with greater endocortical wall thickness, fewer canals, greater osteoid thickness by greater mineral apposition rate and bone formation rate compared to whites [Schnitzler et al., 2009].

From this perspective, the studied samples of the Upper Palaeolithic $H$. sapiens may reflect various stages of biological adaptation. The most "warm-adapted" AMH seem to be the male Kostenki 14 and female Strashnaya 4, and microscopic patterns of their compact bone may indicate relatively recent migration of their ancestors from the warm environment to Eastern Europe and to Siberia.

Kostenki 14, one of the earliest modern humans in Europe as based on recent AMS dating, is known as morphological antipode of Sunghir 1 male, who lived on the Russian plain thousands years later. $\mathrm{He}$ was low-statured, whereas Sunghir 1 was tall (159-160 cm and 175.3-184.3 cm, respectively) 
[Trinkaus et al., 2014]. He had narrow shoulders, whereas Sunghir 1 demonstrated extraordinary wide shoulders, and consequently, great lung capacity. Moreover, K14 inherited tropical longitudinal proportions, whereas S1 was cold adapted in this regard (radio-humeral index: $80.7 / 80.13$ for K14 and 78.5/78.9 for S1; tibial-femoral index: $81.6 / 81.8$ for K14 and 84.9/84.4 for S1).

Based on ratio of the inner robusticity of his phalanx and its relative vascularization Sunghir 1 is the fossil human most similar to Eskimo male under comparison. Other AMH humans from excavations of Kostenki 8 and Abri Pataud, which have relatively thicker walls, also demonstrate biological response to the cold stress. And the most developed system of vascular vessels of compact is noted in young woman Abri Pataud 26227 who lived during the most remarkable glaciation of Magdalenian.

When European Neanderthals La Ferrassie 1, Kiik-Koba 1 show features that can be interpreted as biological adaptation to cold stress of Glacial Age, Neanderthals found in Altai caves appear to have very diverse compositions of traits, which are not easy to interpret.

Neanderthals in Altai were not living in periglacial conditions. The climate of the low-elevation zone of the Altai was milder than in Europe, and there were never glaciers here [Деревянко c соавт., 2003]. Hypothetically, the relatively moderate climate could favor the existence of wide adaptive norm, resembling patterns occurring in former environments among inhabitants of the region.

Collaboration of archaeologists, palaeogenetists and specialists in the field of absolute dating led to sensational conclusion about the hybridization of Denisovans and Neanderthals, during the long period (150-50 ka) they jointly inhabited South Siberia [Slon et al., 2018].

According to genetic data, the first Neanderthal migrants to Altai were the descendants of a palaeopopulation who had genetic contacts with representatives of anatomically modern humans, presumably in the Middle East [Prufer et al., 2013; Kuhlwilm et al., 2016]. It was recently suggested, that gene flow from Denisovans to Neanderthals happened 4,500 $\pm 2,100$ years before Altai Neanderthal Denisova 5 lived (known by results of the highquality genome sequence and excavated in layer 11.4, e.g. later than Denisova 9) [Peter, 2020].
Subsequent wave of Neanderthal migration to the Altai highland was associated with kinship ties with Neanderthals in Europe [Kolobova et al., 2020; Mafessoni et al., 2020].

However, Denisovans and Neanderthals of different origins were not the only inhabitants of Eurasia, and traces of a possibly more relict population were found in their gene pool. Progress in the field of population genetics and bioinformatics allows discussing the episodes of hybridization of fardiverged groups of the Pleistocene humans at a new level. It was argued that the common ancestor of Denisovans and Neanderthals was separated from the ancestors of the anatomically modern humans about 750 thousand years ago. Modeling confirmed episodes of hybridization that led to the induction of genes from relict Homo sp. to Denisovans and from the early sapiens to the Altai Neanderthals. Besides, presumably, there was an earlier episode of crossing these archaic Homo with a population of common Neanderthal and Denisovan ancestors [Rogers et al., 2020].

Distal phalanx Denisova 9 unearthed from stratum 12 of the eastern gallery of Denisova Cave in 2011 is the chronologically earliest specimen in our sample panel and belongs to representative of genetically distinctive group of Altai Neanderthals [Prufer et al., 2014; Sawyer, 2016]. Among Neanderthals, it shows not only the highest level of wall corticalization, comparable with patterns of "warmadapted" anatomically modern human Kostenki 14, but also has one of the most vascularized compact bone tissue. The latter peculiarity may be interpreted as some morphological and physiological response, which compensated for extraordinary robusticity of walls.

Moreover, preliminary examination by different radiological methods discovered unusual inner structure of this phalanx [Mednikova, 2013, 2020b]. The internal space of its distal tuberosity was formed by strong, extremely robust and dense trabeculae consisting of bone material; this area, usually associated with medullary cavity, was completely osteonized.

We suggested earlier that this condition resembles radiologically established patterns of the "ivory structure" in epiphyses of some modern humans, often of African ancestry [Kuhns et al., 1973; Shaw, Bohrer, 1979; Herman et al., 1986; Laan van
•• Вестник Московского университета. Серия ХХІІІ. • Антропология • № 1/2021: 93-108 •
- Moscow University Anthropology • Bulletin • 2021, no. 1, pp. 93-108• 
der, Thijn, 1986; Mednikova, 2020b]. Taking into account metabolic activity of the bone marrow, where blood contacts bone tissue, supplying mineral salts and regulatory factors [Krikun, 1985], the higher density of vascular net in the compact bone of Denisova 9 should provide for satisfactory metabolic levels in individual with such peculiarity in nontropical environment.

Concerning the inner robusticity of tubular bones, the opposite morphological variant of extremely thin walls was detected in other group of Neanderthals from Chagyrskaya cave [Mednikova et al., 2017; Mednikova, 2020b], who had clear European origin [Mafessoni et al., 2020]. Based on the development of the compact bone vascular system, the Chagyrskaya Neanderthal was classified as hyper-cold adapted. That can reflect former environment of this group in glacial climate or even genetic contacts with other humans adapted to cold and hypoxic mountain conditions. And the best candidates for those other humans adapted to hypoxia in highland are Denisovans who $160 \mathrm{ka}$ ago settled in the Tibetian plateau and $300 \mathrm{ka}$ ago settled in Altai [Деревянко, 2009; Zhang et al., 2020]. A remarkable example of hybridization of Neanderthals of Chagyrskaya lineage and Denisovans was provided by the study of the female tubular bone Denisova 11. This girl was an offspring of a Denisovan father and a Neanderthal mother [Slon et al., 2018].

According to archaeological data, the Okladnikov and Chagyrskaya caves jointly point to the presence of Neanderthals of a same cultural circle, who produced a local Sibiryachikha variety of the Mousterian industry [Деревянко, Маркин, 1992; Деревянко с соавт., 2013]. But the morphological type of Okladnikov Neanderthals seems to be quite different [Mednikova, 2011, 2015]. The current examination reveals the combination of robust walls and very low vascularization degree close to recent individual of African ancestry, the Upper Palaeolitic sapiens Strashnaya 4 and Kostenki 14. But how could Neanderthals from Okladnikov cave be so "warm-adapted"?

Excavated in 1984 the fragmentary remains from Sibiryachikha (then Okladnikov) cave were identified as Neanderthal by the study of mitochondrial DNA [Krause et al., 2007]. Due to peculiarities of postcranial morphology, they seem be more similar to Tabun C1 Levant Neanderthal and show some "erectoid" and quite unique features [Mednikova, 2011]. Further attempts to get more conclusive genetic or chronological data crashed against the contamination of the cave by recent organic material because of neighbouring village's activity.

However, based on data of their vascular development, this particular group of Neanderthals, who used Mousterian-like tools, might be mixed with people of recent tropical origin. The presence of the anatomically modern humans in Strashnaya indicates their relatively early coming to Altai. Therefore, hypothetically speaking, hybridization of these branches may be present. The recent study comprises the worldwide expansion of tropical anatomically modern humans between 40 and 60 thousand years ago and their last known contacts with archaic groups of Neanderthals and Denisovans [Bergstrom et al., 2021].

We suggested earlier that Denisova and Okladnikov Neanderthals could belong to one lineage, the real "Altai Neanderthals" [Mednikova et al., 2017]. Now, in view of our present radiological studies, we may cautiously note that early Neanderthals from Denisova and later Okladnikov Neanderthals show different adaptive features as various signs of contacts of their ancestors with warm-adapted humans.

\section{Conclusion}

Modern radiological techniques provide new ways to characterize macro- and microscopic morphology patterns of bone and teeth structures in extant and fossil hominids. Micro-CT and X-ray microscopy makes it possible to do non-destructive 3D high-contrast structural imaging at micron resolution, with local microtomography of small regions of interest within a larger sample. Manual phalanges often present in fossil record carry information about both age and individual constitution. In the present study $3 \mathrm{D}$ and $2 \mathrm{D}$ reconstructions of microstructural bone features were made and analyzed. Significant differences in development of the vascular system feeding the compact of bone may reflect variations in intravital heat exchange parameters and general degree of biological adaptation to ambient temperatures. Distinct morphological and physiological differences observed for native inhabitants of Arctic and tropical regions largely determine their different metabolic features and rates.
• Вестник Московского университета. Серия ХХIII. • Антропология • № 1/2021: 93-108 •
- Moscow University Anthropology • Bulletin • 2021, no. 1, pp. 93-108 • 


\section{4}

Based on 3D non-destructive microstructural study of vascular development inside small tubular bones we suggest different adaptive trends in the Upper Pleistocene fossils of Eurasia, even among representatives of one taxon (e.g. Neanderthals or Homo sapiens). It could relate to different chronology, migrations from contrasting (tropic versus glacial) environments and/or hybrid ancestry.

The combination of high vascularization of compact and signs of inner robusticity in manual phalanges of Upper Palaeolithic sapiens (individuals from excavations of sites Kostenki 8, Abri Pataud) and European Neanderthals (La Ferrassie 1, Kiik-Koba 1) clearly demonstrate biological adaptation to the Glacial Age environment. Sunghir 1 is a fossil human most similar to Eskimo male under comparison, but many others anatomically modern humans and Neanderthals had higher vascularization and, consequently, may be more cold-adapted. Among Upper Palaeolithic samples studied, the early CroMagnon Kostenki 14 (Eastern Europe) and female Strashnaya 4 (Altai) have features in common with humans of recent tropic origin, such as a low development of vascular net inside the bone tissue.

Specimens of Neanderthals that lived in the Altai region where glaciers never occurred are more diverse and reflect various stages of biological adaptation. Hypothetically, the milder climate could favor the existence of a wider adaptive norm reflecting patterns of former environments, from where ancestors of Altai Neanderthals, Denisovans or local anatomically modern humans migrated.

The chronologically earlier Denisova 9 represents a genetically distinctive group of Altai Neanderthals. The phalanx has the "ivory" structure, often encountered in modern humans of African ancestry. Among Neanderthals, it shows the highest level of walls corticalization similar to that found in "tropically adapted" anatomically modern human Kostenki 14, and it features one of the most vascularized compact bone tissue. The high density of vascular net in compact bone of Denisova 9 should provide for satisfactory metabolic levels in an individual with such peculiarity in non-tropic environment.

Chagyrskaya Neanderthal belongs to other genetic group connected to Europe and demonstrates the hyper-cold adaptation combining thin- nest compact and the highest vascular development. Surprisingly, Neanderthals from Okladnikov cave, who are associated with the same local Sibiryachikha variety of the Mousterian industry, were "hot-adapted" and resemble samples of recent African origin similar to anatomically modern sapiens from Strashnaya cave. We can assume that somewhat ambiguous morphological patterns of Denisova 9 and Okladnikov 2, 5 reflect various episodes of Neanderthal migration to Siberia and their hybridization with people of tropical ancestry, most probably the early anatomically modern humans.

The further development of this approach should be aimed at studying the variability within and between different tubular bones, with the study of ontogenetic trajectory of cold and warm-adapted profiles of bone tissue (both growth and aging) and with gathering of representative database of recent inhabitants of various distinctive climes.

\section{Acknowledgements}

Study was provided as a part of government assignment, topic AAAA-A18-118011790092-5. M.M. is grateful to Dr. A.P. Derevyanko, Dr. M.V. Shukov, Dr. A.I. Krivoshapkin, Dr. S.V. Markin (Institute of Archaeology and Ethnography of the Siberian Branch RAS) for the opportunity to study Siberian fossils; Mr. Victor Zagvozdin, former "Systems for Microscopy and Analysis" for technical support; to the Museum of Natural History in Paris and to Dr. A. Froment, Ph. Mennecier, V. Laborde, to Dr. V. Khartanovich (Kunstkamera RAS, Saint Petersburg), to Dr. T.S. Balueva + (Institute of Ethnology and Anthropology, RAS), who granted access to comparative material.

\section{References}

Alexeeva T.I. Geograficheskaya sreda I biologiya cheloveka [Geographic environment and human biology]. Moscow, Mysl Publ., 1977. 302 p. (In Russ.).

Derevianko A.P. Perekhod ot srednego k verknemu paleolitu I problema formirovaniya Homo sapiens sapiens $v$ Vostochnoy, Zentralnoy I Severnoy Asii [Transition from the Middle to Upper Paleolithic and the problem of the formation of Homo sapiens sapiens in East, Central and North Asia]. Novosibirsk: IAET RAS Publ., 2009. 327 p. (In Russ.).

Derevianko A.P., Markin S.V. Mustie Gornogo Altaya (po materialam peshery im.Okladnikova) [Moustier of 
Altai Mountains (based on data from Okladnikov Cave)]. Novosibirsk: Nauka Publ., 1992. 224 p. (In Russ.).

Derevianko A.P., Shunkov S.V., Agadjanian A.K., Baryshnikov G.F., et al. Prirodnaya sreda i chelovek v paleolite Gornogo Altaya: usloviya obitaniya v okrestnostyah Denisovoy Peshery [Environment and human in the Palaeolithic of Mountain Altai: living conditions in surrounding of Denisova Cave]. Novosibirsk: IAET RAS Publ., 2003. 447 p. (In Russ.).

Mednikova M.B. Kist sungirza. Novye dannye o stroenii trubchatykh kostei [Hand of Sunghir 1(new data about built of tubular bones)]. Moscow University Anthropology Bulletin [Vestnik Moskovskogo universiteta. Seria XXIII. Antropologiya], 2012, 4, pp. 4-17. (In Russ.).

Mednikova M.B., Moiseyev V.G., Khartanovich V.I. Stroenie trubchatykh kostey kisti u obitateley verkhnepaleoliticheskih stoyanok Kostenki 14 | 8 (evoluzionny I bioarckheologicheski aspekty) [Structure of manual tubular bones of inhabitants of Upper Palaeolithic sites Kostenki 14 and 8 (evolutionary and bioarchaeological aspects]. Moscow University Anthropology Bulletin [Vestnik Moskovskogo universiteta. Seria XXIII. Antropologiya], 2016, 1, pp. 20-34. (In Russ.).

Khrissanfova E.N. Postkranialnyi skelet vsroslogo muzhchiny Sunghir 1. Bedrennaya kost Sunghir 4 [Poscranial skeleton of male Sunghir 1. Femur Sunghir 4]. In Sunghir Antropologicheskoe issledovanie [Sunghir. Anthropological research]. Moscow: Nauka Publ., pp. 100-140. (In Russ.).

Abbott S., Trinkaus E., Burr D.B. Dynamic bone remodeling in later Pleistocene fossil hominids. Am. J. Phys. Anthropol., 1996, 9, pp. 585-601.

Asghar A., Kumar A., Narayan R., Naaz Sh. Is the cortical capillary renamed as the transcortical vessel in diaphyseal vascularity? Anat. Rec., 2020, 303 (11), pp. 2774-2784.

Bergstrom A., Stringer C., Hajdinjak M., Scerri E.M.L., Skoglund P. Origins of modern human ancestry. Nature, 2021, 590, pp. 229-237.

Buckwalter J. A., Glimcher M. J., Cooper R. R., Recker R. Bone biology. J. Bone Joint Surg. Am. 1995, 77, pp. 1256-1275.

Cho H., Stout S.D., Madsen R.W., Streeter M.A. Population-specific histological age-estimating method: a model for known African-American and European-American skeletal remains. J. Forensic Sci., 2002, 47, pp. 12-18.

Cho H., Stout S.D., Bishop T.A. Cortical Bone Remodeling Rates in a Sample of African American and European American Descent Groups from the American Midwest: Comparisons of Age and Sex in Ribs. Am. J. Phys. Anthropol., 2006, 130, pp. 214-226.

Dobrovolskaya M., Mednikova M. Vascular system of human compact bone tissue: a tool of the microscopic study for the microevolution processes reconstruction. Proceedings of the European Society for the study of Human Evolution, 2016, 5, p. 82.

Jaffe H.L. The vessel canals in normal and pathological bone. Am. J. Pathol., 1929, 5 (3), pp. 323-332.

Eagan C. J. Local vascular adaptations to cold in man. Fed. Proc., 1963, 22, pp.947-951.

Frost H.M. Secondary osteon populations: An algorithm for determining mean bone tissue age. Yearbook Phys. Anthropol., 1987, 30, pp. 221-238.

Herman T.E., Crowford J.D., Cleveland R.H., Kushner D.C. Hand radiographs in Russel-Silver syndrome. Pediatrics, 1986, 79, pp. 743-745.
Iwaniec U., Grenshaw T.D., Schoeninger M.G., Stout S.D., Ericksen M.F. Methods for improving the efficiency of estimating total osteon density in the human anterior mid-diaphyseal femur. Am. J. Phys. Anthropol., 1998, 107, pp. 13-24.

Kerley E.R. The microscopic determination of age in human bone. Am. J. Phys. Anthropol., 1965,23, pp.149-164.

Krikun M.E. Red-yellow marrow conversion: its effect on the location of some solitary bone lesions. Skeletal Radiology, 1985, 14, pp.10-19.

Kuhlwilm M., Gronau I., Hubisz M.J., de Filippo C., PradoMartinez J. et al. Ancient gene flow from early modern humans into Eastern Neanderthals. Nature, 2016, 530, pp. 429433.

Kuhns L.R., Poznanski A.K., Harper H.A.S., Garn S.M. Ivory epiphyses in the hands. Pediatric Radiology, 1973, 109, pp. 643-648.

Kolobova K., Roberts R.G., Chabai V.P. et al. Archaeological evidence for two separate dispersals of Neanderthals into southern Siberia. Proceedings of National Academy of Sciences, 2020. 117(6), p.28-79. DOI: 10.1073/pnas.19180471217.

Krause J., Orlando L., Serre D., Viola B., Prüfer K. et al. Neanderthals in central Asia and Siberia. Nature, 2007, 449, pp. 902-904.

Laan van der J.G., Thijn C.J.P. Ivory and dense epiphyses of hand: Thimann disease in three sisters. Skeletal Radiology, 1986, 15, pp.117-122.

Little M.A., Thomas R.B., Mazess R.B., Baker P.T. Population differences and developmental changes in extremity temperature responses to cold among Andean Indians. Hum. Biol., 1971, 43. pp. 70-91.

Mafessoni F., Grote S., de Filippo C., Slon V., Kolobova K. et al. A high-coverage Neandertal genome from Chagyrskaya Cave. bioRxiv preprint, 2020. DOI: https://doi.org/10.1101/2020.03.12.988956.

Marom A., McCullagh J., Higham T., Sinitsyn A.A., Hedges R. Single amino acid radiocarbon dating of Upper Paleolithic modern humans. Proceedings of the National Academy of Sciences of the United States of America, 2012, 109 (18), pp. 6878-6881.

Mednikova M.B. Postcranial morphology and taxonomy of genus Homo representatives from Okladnikov Cave in Altai. Novosibirsk: IAET SO RAN, 2011. 127 p.

Mednikova M.B. Distal phalanx of the hand of Homo from Denisova cave stratum 12: a tentative description. Archaeology, Ethnography and Anthropology of Eurasia, 2013, 4, pp. 146-155.

Mednikova M. Altai Neanderthals and their morphological diversity. Proceedings of the European Society of Human Evolution, 2015, 4, p. 159.

Mednikova M. Heat or Cold Adaptation in Pleistocene Humans: Evidence of Vascular System Development in Tubular Bones. Proceedings of the European Society for the study of Human Evolution, 2018, 6, p.138.

Mednikova M. Concerning Patterns of Biological Adaptation among Eurasian Pleistocene Hunter-gatherers. 26th EAA Virtual Annual Meeting Abstract Book, 2020a, p. 312.

Mednikova M.B. Distal Manual Phalanges of Upper Pleistocene Homo from Altai Caves. Moscow University Anthropology Bulletin, 2020b, 2, pp. 5-25. DOI: 10.32521/2074-8132.2020.2.005-025.

Mednikova M.B., Dobrovolskaya M.V., Viola B., Lavrenyuk A.V., Kazansky P.R. et al. A Micro Computerized Tomography (X-Ray Microscopy) of the Hand Phalanx of the Denisova Girl. Archaeology, Ethnography and Anthropology of Eurasia, 2013, 41, pp. 120-125.
• Вестник Московского университета. Серия ХХІІІ. • Антропология • № 1/2021: 93-108 •
- Moscow University Anthropology •

Bulletin • 2021, no. 1, pp. 93-108 • 
Mednikova M., Dobrovolskaya M., Vascular system development of small tubular bones of Neanderthals from Altai caves. Proceedings of the European Society of Human Evolution, 3, 2014, p. 115.

Mednikova M.B., Shunkov M.V., Markin S.V. Robusticity of Hand Phalanges: Relevance to the Origin of the Altai Neanderthals. Archaeology, Ethnography and Anthropology of Eurasia, 2017, 45 (3), pp. 126-135. DOI: 10.17746/1563-0110.2017.45.3.126-135.

Mulhern D.M. Rib Remodeling Dynamics in a Skeletal Population from Kulubnarti, Nubia. Am. J. Phys. Anthropol., 2000, 111, pp. 519-530.

Nalawade-Chavan S., McCullagh J., Hedges R. New hydroxyproline radiocarbon dates from Sungir, Russia, confirm Early Mid Upper Palaeolithic burials in Eurasia. PLOS ONE, 9 (1), 2014. e76896.

Qui S., Fyhrie D.P., Palnitkar S., Rao S.D. Histomorphometric assessment of haversian canal and osteocyte lacunae in different-sized osteons in human rib. Anat. Rec. A Discov. Mol. Cell. Evol. Biol., 2003, 272A, pp. 520-525.

Peter B.M. 100,000 years of gene flow between $\mathrm{Ne}-$ andertals and Denisovans in the Altai mountains. bioRxiv preprint, 2020. DOI.org/10.1101/2020.03.13.990523

Pirock D.J., Ramser J.R., Takahashi H., Villanueva A.R., Frost H.M. Normal histological, tetracycline and dynamic parameters in human, mineralized bone section. Henry Ford Hospital Med. J., 1966, 14, pp.195-218.

Pfeifer S. Variability in Osteon Size in Recent Human Populations. Am. J. Phys. Anthropol., 1998, 106, pp. 219-227.

Pfeifer S., Zehr M.K. A morphological and histological study of the human humerus from the Border Cave. J. Hum. Evol., 1996, 31, pp. 49-59.

Prufer K., Racimo F., Patterson N., Jay F., Sankararaman $\mathrm{S}$. et al. The complete genome sequence of a $\mathrm{Ne}-$ anderthal from the Altai Mountains. Nature, 2014, 505, pp. 43-49.

Robling A.G., Stout S.D. Morphology of drifting osteon. Cell Tissue Organs, 1999, 164, pp.192-204.

Rogers A.R., Harris N.S., Achenbach A.A. Neanderthal-Denisovan ancestors interbred with a distantly related hominin. Science Advances, 6, 2020, eaay5483. DOI: $10.1126 /$ sciadv.aay5483.

Ruff Ch.B. Biomechanical analyses of archaeological human skeletons. In Biological Anthropology of the Human Skeleton, M.F. Katzenberg, Sh.R. Saunders (eds.). New York: Wiley-Liss, Inc., 2000, pp. 71-102.

Sawyer S. Insights into Neandertals and Denisovans from Denisova cave. Dissertation. Universitat Leipzig, 2016. 139 p.

Schnitzler C.M., Mesquita J.M., Pettifor J.M. Cortical bone development in black and white South African children: Iliac crest histomorphometry. Bone, 44, 2009, pp.603-611.

Schultz M. Paleohistopathology of bone: a new approach to the study of ancient diseases. Yearbook of Physical Anthropology, 2001, 44, pp.106-147.

Shaw H.A., Bohrer S.P., The incidence of Cone Epiphyses and Ivory Epiphyses of the Hand in Nigerian Children. Am. J. Phys. Anthropol., 1979, 51, pp. 155-162.

Slon V., Mafessoni F., Vernot B., de Filippo C., Grote S. et al. The genome of the offspring of a Neanderthal mother and a Denisovan father. Nature, 2018, 561 (7721), pp. 113116. DOI.org/10.1038/s41586-018-0455-x.
106

So J.K. Human Biological Adaptation to Arctic and Subarctic Zones. Annual Review of Anthropology, 1980, 9, pp. 63-82.

Stout S.D., Paine R.R. Brief communication: histological age estimation using rib and clavicula. Am.J. Phys. Anthropol., 1992, 87, pp. 111-115.

Stout S.D., Stanley S.C. Percent osteonal bone versus osteon counts: the variable of choice for estimating age at death. Am.J. Phys. Anthropol., 1991, 86, pp. 515519.

Stout S.D., Teitelbaum M.D. Histomorphometric determination of formation rates of archaeological bone. Calcif. Tiss. Res., 1976, 21, pp. 163-169.

Trinkaus E., Buzhilova A.P., Mednikova M.B., Dobrovolskaya M.V. The People of Sunghir. Burials, Bodies, and Behavior in the Earlier Upper Paleolithic. Oxford: Univ. Press, 2014. 420 p.

Viola B., Mednikova M., Buzhilova A. The human remains from Chagyrskaya Cave: An illustrated catalogue and preliminary interpretations. Multidisciplinary Studies of Chagyrskaya Cave - A Middle Paleolithic Site in Altai. Novosibirsk: IAET, 2018, pp. 413-432.

Zhang D., Xia H., Chen F. et al. Denisovan DNA in Late Pleistocene sediments from Baishiya Karst Cave on the Tibetan Plateau. Science, 370, pp.584-587.

\section{Information about Authors}

Mednikova Maria B., PhD, D.Sci.; ORCID ID: 0000-0002-1918-2161; medma_pa@mail.ru; Kazanskiy Pavel R., Dr. Rer. Nat.; ORCID ID: 0000-0002-9406-5184; kazansky@microscop.ru. 
Медникова М.Б. ${ }^{1)}$, Казанский П.Р. ${ }^{2)}$

1) Институт археологии РАН,

ул. Дм. Ульянова, 19, Москва, 117036, Россия

2) ООО «Системь микроскопии и анализа»,

Сколковское шоссе, д. 45, офис 20, Москва, 121353, Россия

\section{НЕДЕСТРУКТИВНАЯ ОБЬЕМНАЯ МИКРОСКОПИЯ В ИЗУЧЕНИИ ОСОБЕННОСТЕЙ БИОЛОГИЧЕСКОЙ АДАПТАЦИИ СРЕДИ ИСКОПАЕМЫХ И СОВРЕМЕННЫХ НОМО}

Введение. Уровень метаболизма и параметры теплообмена играют важную роль в биологической адаптации человечества в разных климатических условиях. Микроскопическое изучение и рассмотрение объемных характеристик костной ткани помогают нам понять, как общие адаптивные особенности конституции человека могут быть запечатлены в микроструктурных вариациях метаболического уровня.

Цель работы заключалась в исследовании микроструктурного разнообразия костной ткани у азиатских и европейских ископаемых гоминид разного происхождения, живших в эпоху плейстоцена, с целью выделения диагностических признаков для фрорм, адаптированных к холодному и теплому климату.

Материалы и методы. В данном исследовании мы использовали метод объемного определения (волюметрии) плотности васкулярной сети в компактном веществе. Сегментация Гаверсовых каналов и точное вычисление их относительного объема позволяют опосредованно определить плотность и вместимость васкулярной системы в костной ткани. Были изучены радиологические изображения дорзальной компакты медиальных и дистальных фраланг (неандертальцы с Алтая и из Европы; кроманьонцы; современные люди арктического и африиканского происхождения).

Результаты. Высокая васкуляризация компакты отчетливо демонстрирует, что европейские неандертальцы и большинство анатомически современных людей были адаптированы к ледниковой эпохе. Но Костенки 14 (Восточная Европа) и Страшная 4 (Алтай) сближаются с современными людьми тропического происхождения. Образцы от неандертальцев алтайского региона, который никогда не был связан с распространением ледника, более разнообразны. Гипотетически, более мягкий климат мог способствовать сохранению широкой адаптивной нормы, вобравшей черты прежних сред обитания. Двойственные морфологические особенности Денисова 9, Окладников 2, 5, по-видимому, запечатлели различные эпизоды неандертальской миграции в Сибирь и их гибридизацию с людьми тропического происхождения, наиболее вероятно, с ранними анатомически современными людьми. Неандерталка из Чагырской пещеры демонстрирует гиперадаптацию к холоду.

Заключение. Разнообразие микроструктурных особенностей скелетной системы у людей эпохи плейстоцена доказывает, что неандертальцы и кроманьонцы были полиморфны в адаптивных реакциях по отношению к климату и что обе группы включали формы, предположительно адаптированные к холодным и теплым условиям.

Ключевые слова: неандертальцы; кроманьонцы; теплообмен; васкуляризация компакты трубчатых костей 


\section{Библиография}

Алексеева Т.И. Географическая среда и биология человека. М.: Мысль, 1977. 302 с.

Деревянко А.П. Переход от среднего к верхнему палеолиту и проблема формирования Homo sapiens sapiens в Восточной, Центральной и Северной Азии. Новосибирск: Изд-во ИАЭТ СО РАН, 2009. 327 с.

Деревянко А.П., Маркин С.В. Мустье горного Алтая (по материалам пещеры им.Окладникова). Новосибирск: Наука, 1992. 224 с.

Деревянко А.П., Шуньков М.В., Агаджанян А.К., Барышников Г.Ф., et al. Природная среда и человек в палеолите Горного Алтая: условия обитания в окрестностях Денисовой пещеры. Новосибирск: Изд-во ИАЭТ СО РАН, 2003. 447 c.

Медникова М.Б. Кисть сунгирца. Новые данные о строении трубчатых костей // Вестник Московского университета. Серия XXIII. Антропология, 2012. № 4. С. 4-17.

Медникова М.Б., Моисеев В.Г., Хартанович В.И. Строение трубчатых костей кисти у обитателей верх-

\section{8}

непалеолитических стоянок Костенки 14 и 8 (эволюционный и биоархеологический аспекты) // Вестник Московского университета. Серия XXIII. Антропология, 2016. № 1. С. 20-34.

Хрисанфоова Е.Н. Посткраниальный скелет взрослого мужчины Сунгирь 1. Бедренная кость Сунгирь 4 / Сунгирь. Антропологическое исследование. М.: Наука, 1984. C.100-140.

\section{Сведения об авторах}

Медникова Мария Борисовна, д.и.н., ORCID ID: 0000-0002-1918-2161; medma_pa@mail.ru;

Казанский Павел Роальдович; ORCID ID: 0000-0002-9406-5184; kazansky@microscop.ru.

Поступила в редакцию 19.02.2021, принята к публикации 14.03.2021. 